\title{
Forest Carbon Stocks in Lowland Area of Simien Mountains National Park: Implication for Climate Change Mitigation
}

\author{
Tibebu Yelemfrhat Simegn, Teshome Soromessa* and Eyale Bayable
}

Center for Environmental Science, Addis Ababa University, Post Box No: 1176, Addis Ababa, Ethiopia

\begin{tabular}{|c|c|}
\hline Abstract & Article Information \\
\hline \multirow{12}{*}{$\begin{array}{l}\text { Forests play a significant role in climate change mitigation by sequestering and storing } \\
\text { more carbon from the atmosphere which was released by anthropogenic causes. The } \\
\text { overall objective of this study was to estimate carbon stock potential of lowland forest of } \\
\text { Simien Mountains National park for climate change mitigation. And it aimed to add } \\
\text { values of the lowland forest of the park for climate change mitigation contribution in } \\
\text { Ethiopia. The work was accomplished properly using random sampling to estimate the } \\
\text { forest carbon in above and below ground biomass by considered each trees and } \\
\text { shrubs which had DBH } \geq 5 \mathrm{~cm} \text {. Above ground biomass was estimated by using } \\
\text { allometric models equation of Brown (1998) while below ground biomass was } \\
\text { determined based on the ratio of below ground biomass to above ground biomass } \\
\text { factors of (MacDicken, } 1997 \text { ). Dead wood, leaf litter, herb and grass (LHG) and soil } \\
\text { organic carbon were conducted according to sampling quadrates data and laboratory } \\
\text { result. The results shown that, there were twenty species with a density of } 2334 \text { trees } \\
\text { and shrubs in the study sites which had DBH } \geq 5 \text { cm. The mean above ground and } \\
\text { below ground biomass carbon stock were } 270.89 \pm 154.50 \text { and } 54.18 \pm 30.81 \text { t ha }{ }^{-1} \\
\text { respectively. The mean above ground biomass carbon per species was } 20.42 \pm 17.99 \\
\text { ton. The mean carbon in dead wood, LHG and soil carbon were } 0.7258 \pm 1.0479 \text {, } \\
0.019 \pm 0.008 \text { and } 242.51 \pm 46.42 t \text { ha }{ }^{-1} \text { respectively. } \\
\text { Copyright } @ 2014 \text { STAR Journal. All Rights Reserved. }\end{array}$} & Article History: \\
\hline & Received : 15-06-2014 \\
\hline & Revised \\
\hline & Accepted : $27-0$ \\
\hline & Keywords: \\
\hline & Carbon stock \\
\hline & Climate change Mitigation \\
\hline & Simien Mountains National Park \\
\hline & \\
\hline & \\
\hline & Teshome Soromessa \\
\hline & E-mail: \\
\hline
\end{tabular}

\section{INTRODUCTION}

Carbon sequestration is the process of removing excess carbon dioxide $\left(\mathrm{CO}_{2}\right)$ from the atmosphere and depositing it in a reservoir (UNFCCC, 1997). It is a way to mitigate the accumulation of greenhouse gases in the atmosphere released by the burning of fossil fuel and other anthropogenic activities. Through biological, chemical or physical processes, $\mathrm{CO}_{2}$, which is one of the greenhouse gases, can be captured from the atmosphere. While a carbon sink is a reservoir that collects and stores carbon containing chemical compound, it removes $\mathrm{CO}_{2}$ from the atmosphere through absorption. Forest and soil are potential sinks for elevated $\mathrm{CO}_{2}$ emissions and are being considered in the list of acceptable offsets (UNFCCC, 1997). Sustainable forest development and forested landscape expansion is one of the key approaches for reducing atmospheric carbon concentration. It is a safe, environmentally acceptable, and cost-effective way to capture and store substantial amounts of atmospheric carbon. The concurrent development of tradable carbon credits provides financial incentives for considering carbon storage in forest management decisions (Siry et al., 2006).

Carbon sequestration from atmosphere can be advantageous from both environmental and socioeconomic perspectives. There are evidences from several studies in Ethiopia and other countries. The environmental perspective includes the removal of $\mathrm{CO}_{2}$ from the atmosphere (Yitebitu Moges et al., 2010), the improvement of soil quality, and the increase in biodiversity (Batjes and Sombroek, 1997); while socioeconomic benefits include increased yields (Sombroek et al., 1993), monetary incomes from potential carbon trading schemes (McDowell, 2002), normalizing droughts through its potential for creating atmospheric condensation making cloud seeding, as well as reducing flood hazards and increasing ground water recharge by increasing water infiltration through soil columns. Globally, forests act as a natural storage for carbon, contributing approximately $80 \%$ of terrestrial above-ground, and $40 \%$ of terrestrial belowground biomass carbon storage (Kirschbaum, 1996). So biomass is an important element in the carbon cycle, specifically carbon sequestration. It is used to help to quantify pools and fluxes of green house gases (GHG) from the terrestrial biosphere to the atmosphere associated with land use land cover changes (Cairns et al., 2003). There are many conventional methods for quantification of sequestered carbon. Many of these methods are complicated, expensive and limited in their coverage. Such limitations impede sound quantification and monitoring of carbon (MacDicken, 1997). One of such approaches is forest inventory data sets which often provide the required base line data to enable the large area mapping of biomass and 
Tibebu Yelemfrhat et al.,

subsequent carbon accounting over a range of spatial and temporal scales. However, spatially explicit estimates of biomass over large areas may be limited by the spatial extent of the forest inventory relative to the area of interest (i.e., inventories not spatially exhaustive), or by the omission of inventory attributes required for biomass estimation. These spatial and attribution gaps in the forest inventory may result in an underestimation of large area biomass (Wulder et al., 2008).Many scholars also agreed on significance of studying and documenting the vegetation resources of Ethiopia, inter alia, Teshome Soromessa et al. (2004); Ensermu Kelbessa and Teshome Soromessa (2008); Teshome Soromessa et al. (2011); Fekadu Gurmessa et al. (2011 and 2012); Adugna Feyissa et al. (2013); Teshome Soromessa (2013); Teshome Soromessa and Ensermu Kelbessa (2013a and 2013b); Abel Girma et al. (2014); Belay Melese et al. (2014); Birhanu Kebede et al. (2014); Mohammed Gedefaw et al., (2014); Mohammed Gedefaw and Teshome Soromessa (2014); Teshome Soromessa and Ensermu Kelbessa (2014) are some of them. However, no study has been conducted in Simien Mountains National
Sci. Technol. Arts Res. J., July-Sep 2014, 3(3): 29-36

Park Forest that has been intended at evaluating carbon sequestration potential. Therefore, this study was undertaken to estimate the carbon stock of the lowlands of Simien Mountains National Park in relation to environmental gradients.

\section{MATERIALS AND METHODS \\ Description of the Study Area}

This study was undertaken in lowland forest of Simien Mountains National Park forest (Figure 1), Amhara National Regional State, north Gondar, Ethiopia located at about $846 \mathrm{~km}$ North of Addis Ababa. The forest has an altitudinal gradient ranging from 1900 to $3000 \mathrm{~m}$ above sea level with the highest peak at Ras Dashin Mountain. The forest covers 171 hectares. The study area is characterized by moderate climate, locally known as Woina Dega and it has a mono modal rainfall distribution and the rainy season is from June to August with The annual average rain fall of SMNP $1367 \mathrm{~mm}$ and the mean annual maximum and minimum temperatures are 11 and $19^{\circ} \mathrm{C}$, respectively.

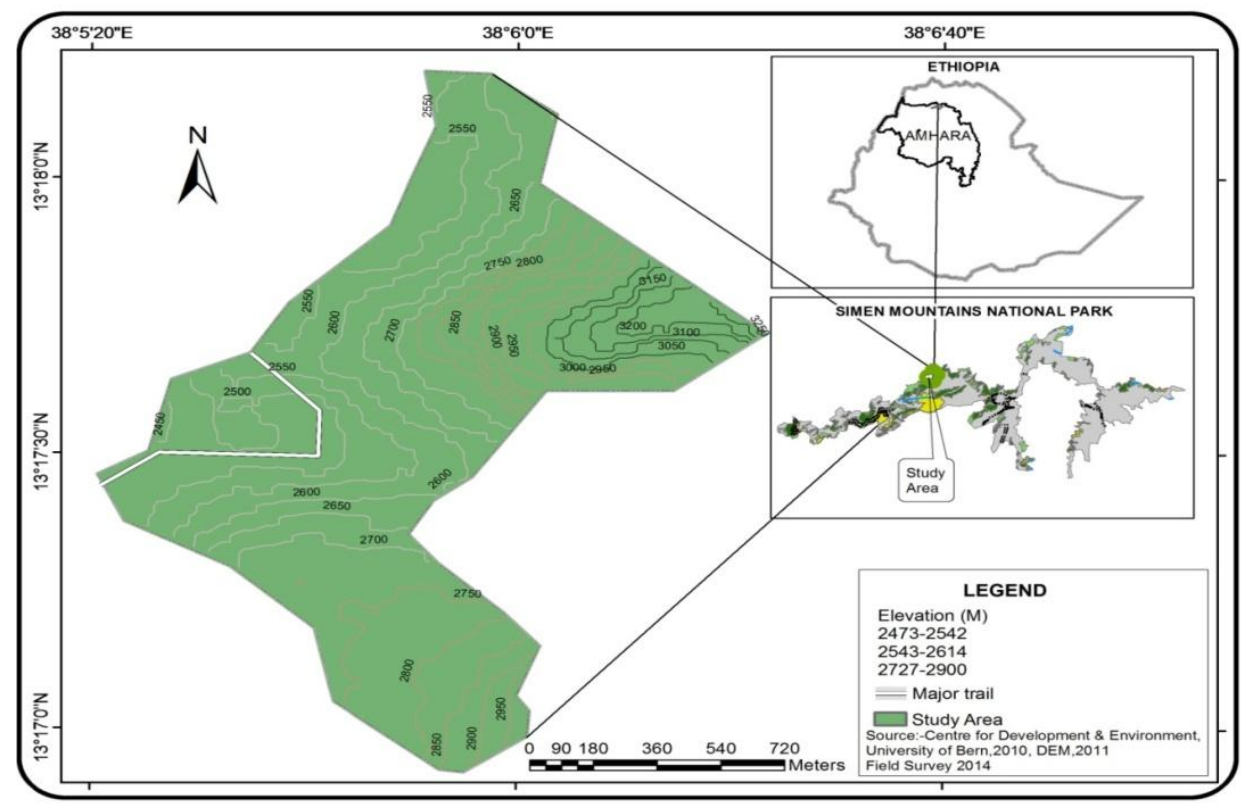

Figure 1: Map of the study area

\section{Delineation of the Study Site}

Delineation of the forest boundaries was the first step in forest carbon stock measurement. The boundary of the study forest area was delineated by taking geographic coordinates with GPS at each turning point. The GPS points that were taken from the study site to indicate each sample plots were recorded.

\section{Sampling Techniques on the Field}

Simple random sampling method was used to take samples. Sample plots were laid along line transects based on altitudinal variation of the study area. A randomly sampling plot of $(10 \mathrm{~m} \times 20 \mathrm{~m})$ in each site was established. To reveal the tree composition and biomass, all live trees with a diameter $\geq 5 \mathrm{~cm}$ were recorded as indicated by (Pearson et al., 2005 and 2007). The diameter was measured at breast height $(\mathrm{DBH}, 1.3 \mathrm{~m}$ height from the ground) to estimate biomass and the size class distribution of trees in a sampling plot. DBH was measured by using tree measuring tape. Trees with multiple stems connected near the ground were counted as single individuals and bole circumference was measured separately. Tree height was recorded by using measuring clinometers. The methodology and procedures used to estimate carbon stocks were simple step by step procedures using standard carbon inventory principles and techniques (Pearson et al., 2005). Procedures were based on data collection and analysis of carbon accumulating in the above ground biomass, below-ground biomass, leaf litter, and soil carbon of forests using verifiable modern methods.

\section{Stratification of the Study Area}

Stratification was done in the forest in order to take accurate data from the field as well as to maintain the homogeneity of the area. Altitude was the major parameter to classify the study area. The strata were defined at each elevation, starting from the bottom to the top of the mountain. Based on altitudinal variation, the study site was stratified into three zones namely: lower (2473-2542 m), middle (2543-2614 m) and higher (2615$2900 \mathrm{~m})$. Slope gradient was the second parameter to 
classify the area. Therefore, slope classes classified into lower $(0-10 \%)$, middle $(>10-20 \%)$ and higher (>20\%). Aspect was also another parameter that was considered in the study forest and classified in to four classes: $N$ (North), S (South), E (East), W (West).

\section{Field Measurements}

Sample plots $(10 \mathrm{~m} \times 20 \mathrm{~m})$ were laid through stratified random sampling method with nine transect lines in the various qualitatively classified biomass levels to account for the largest variability in the biomass range. Ground inventory data of tree parameters i.e., $\mathrm{DBH}$ and height of the trees were collected.

\section{Vegetation Data Collection and Identification}

The estimations of above and below ground carbon depend on the above ground biomass of living tree species. To estimate the above ground biomass all tree species within selected sample plots $\mathrm{DBH} \geq 5 \mathrm{~cm}$ were identified and recorded. Trees with multiple stems at $1.3 \mathrm{~m}$ height were treated as a single individual and $\mathrm{DBH}$ of the largest stem was taken. Plant identification was done by using Flora of Ethiopia and Eritrea.

\section{Field Carbon Stock Measurement}

The major activities of carbon measurement during the field data collection were above-ground tree biomass, below-ground biomass, leaf litter, and soil organic carbon measurements. Detailed methods are explained under the following sub headings.

\section{Above Ground Biomass (AGB)}

The above ground biomass consists of all living vegetation above the soil, inclusive of stems, stumps, branches, bark, seeds and foliage. The DBH (at 1.3m) and height of individual trees greater than or equal to $5 \mathrm{~cm}$ and DBH were measured in each sampling plots.

\section{Litter Biomass (LB)}

The leaf litter is defined as all dead organic surface material on top of the mineral soil. A quadrate with a size of $1 \mathrm{~m} \times 1 \mathrm{~m}$ was established to sample litters. In each sample plots a total of five small quadrates were laid four at the corner and one in the center to minimize heterogeneity. The litter samples were taken in sub quadrate of $(1 \mathrm{~m} \times 1 \mathrm{~m})$ along diagonal from one corner to the other and then the leaf litters within the $1 \mathrm{~m}^{2}$ sub plots were collected. Laboratory analysis: The 100 gram sub sample fresh weights were sampled from the five subsamples collected from each quadrant which were mixed homogenously and then taken to laboratory and oven dried at $105^{\circ} \mathrm{C}$.

\section{Soil Organic Carbon (SOC)}

Soil samples were collected from the field with five sub-plots within each major plot. The Samples were dug using core sampler with a diameter of $5 \mathrm{~cm}$ and the depth of the soil in which that took the sample was $30 \mathrm{~cm}$. Mixing of soils was done properly by taking equal amount of soil from each sub plots to make a composite in order tomake homogeneity. After organizing the samples in such a way, the samples were taken to Wondo Genet College of Forestry and Natural Resources for laboratory analysis. In the laboratory, soils are prepared and oven dried at $105^{\circ} \mathrm{C}$ for 24 hours to remove the soil moisture so as to determine the percentage of organic carbon. Finally, the bulk density and soil organic carbon were determined after getting percentage of organic carbon.

\section{Estimation of Carbon Stocks in Different Carbon} Pools

\section{Estimation of Above Ground Carbon Stock (AGC)}

Bhishma et al. (2010) defined allometric equation as a statistical relationship between key characteristic dimensions of trees that are fairly easy to measure, such as $\mathrm{DBH}$ or height, and other properties that are more difficult to assess, such as above ground biomass. The equation developed by Brown et al (1989), was used to calculate the above ground biomass as given below:

$\mathrm{AGB}=34.4703-8.0671(\mathrm{DBH})+0.6589(\mathrm{DBH} 2) \ldots($ equ.1)

Where, AGB is above ground biomass, $\mathrm{DBH}$ is diameter at breast height.

\section{Estimation of Below Ground Carbon Stock (BGC)}

Below ground biomass estimation is much more difficult and time consuming than estimating aboveground biomass (Geider et al., 2001). Roots play an important role in the carbon cycle as they transfer considerable amounts of Carbon to the ground, where it may be stored for a relatively long period of time. As indicated by MacDicken (1997), standard method for estimation of below ground biomass can be obtained as $20 \%$ of above ground tree biomass i.e., root to shoot ratio value of $1: 5$ is used. The equation is given below:

$\mathrm{BGB}=\mathrm{AGB} \times 0.2$

Where, $B G B$ is below ground biomass, AGB is above ground biomass, 0.2 is conversion factor (or $20 \%$ of AGB).

\section{Estimation of Carbon Stocks in Dead Wood}

The allometric equation confirmed in REDD methodology (2009) was used to estimate the amount of biomass in standing dead wood.

$B S D W=\Sigma_{i}^{n}=013(D / 200)^{2} h^{*} s$

Where, biomass is expressed in $\mathrm{kg}, \mathrm{h}=$ length $(\mathrm{m}), \mathrm{D}=$ tree diameter $(\mathrm{cm})$ and $\mathrm{s}=$ specific gravity $(\mathrm{g} \mathrm{cm}-3)$ of wood. The specific density is estimated at $0.5 \mathrm{~g} \mathrm{~cm}^{-3}$ as default value, but can be around 0.8 for dense hard woods and around 0.3 for very light species in tropical regions (Hairiah et al., 2001).

The carbon content in dead wood is calculated by multiplying total biomass of dead wood with the IPCC (2006) default carbon fraction of 0.47 .

\section{Estimation of Carbon Stocks in the Litter Biomass}

According to Pearson et al. (2005), estimation of the amount of biomass in the leaf litter can be calculated by:

LHGB $=\frac{\text { Wfield }}{\mathrm{A}} * \frac{\text { Wsub_sample (dry) }}{\text { Wsub_sample (fresh ) }} * \frac{1}{10,000} \ldots \ldots \ldots \ldots$. (equ.3)

Where: $\mathrm{LB}=$ Litter biomass $($ ha- 1 )

$\mathrm{W}$ field $=$ Weight of wet field sample of litter sampled within an area of size $1 \mathrm{~m}^{2}(\mathrm{~g}) ; \mathrm{A}=$ Size of the area in which litter were collected (ha);

W sub-sample, dry = Weight of the oven-dry sub-sample of litter taken to the laboratory to determine moisture content $(\mathrm{g})$, and

W sub-sample, fresh = Weight of the fresh sub-sample of litter taken to the laboratory to determine moisture content (g). The carbon content of vegetation is surprisingly constant across a wide variety of tissue types and species. Schlesinger (1991) noted that Carbon content of biomass is almost always found to be between 45 and 
Tibebu Yelemfrhat et al.,

$50 \%$ (by oven dry mass). In many applications, the carbon content of vegetation is estimated by simply taking a fraction of the biomass by multiplying 0.5 .

$$
\mathrm{C}=0.5^{\star} \mathrm{LB}
$$

Where $\mathrm{C}=$ is carbon content by mass, and $\mathrm{LB}=$ is ovendry biomass.

Therefore, total carbon content of litter (ton/ha) $=$ Total dry litter biomass* carbon fraction $\mathrm{CL}=\mathrm{LBM} X \% \mathrm{C} \ldots \ldots$ (equ.5)

Where, $\mathrm{CL}$ is total carbon stocks in the litter in ton/ha, \%C is carbon fraction determined in the laboratory (Pearson et al., 2005).

\section{Estimation of Soil Organic Carbon (SOC)}

The carbon stock of soil was done by using the following formula which is recommended by Pearson et al. (2005) from the volume and bulk density of the soil.

$\mathrm{V}=\mathrm{h} \times \Pi \mathrm{r}^{2}$

Where, $\mathrm{V}$ is volume of the soil in the core sampler in $\mathrm{cm}^{3}$, $\mathrm{h}$ is the height of core sampler in $\mathrm{cm}$, and $\mathrm{r}$ is the radius of core sampler in $\mathrm{cm}$ (Pearson et al., 2005). Moreover the bulk density of a soil sample was calculated as follows:

$\mathrm{BD}=\mathrm{Wav}, \operatorname{dry} / \mathrm{V}$

Where, BD is bulk density of the soil sample per, Wav, dry is average air dry weight of soil sample per the quadrant, $\mathrm{V}$ is volume of the soil sample in the core sampler auger in $\mathrm{cm}^{3}$ (Pearson et al., 2005).

$\mathrm{SOC}=\mathrm{BD} * \mathrm{D} * \mathrm{C}$

Where, $\mathrm{SOC}=$ soil organic carbon stock per unit area $(\mathrm{t}$ ha-1) $\mathrm{BD}=$ soil bulk density $\left(\mathrm{g} \mathrm{cm}^{-3}\right)$,

$\mathrm{D}=$ the total depth at which the sample was taken (30 $\mathrm{cm})$, and $\% \mathrm{C}=$ Carbon concentration (\%).

\section{Estimation of Total Carbon Stock Density}

The total carbon stock is calculated by summing the carbon stock densities of the individual carbon pools of
Sci. Technol. Arts Res. J., July-Sep 2014, 3(3): 29-36

the stratum using the Pearson et al. (2005) formula. Carbon stock density of a study area:

$C T=A G C+B G C+L C+S O C$.

Where, $C T=$ Total Carbon stock for all pools (ton/ha), $\mathrm{AGC}=$ above ground carbon stock (ton/ha), $\mathrm{BGC}=$ below ground carbon stock (ton/ha), LC=litter carbon stock (ton/ha) and SOC= soil organic carbon (ton/ha). The total carbon stock was then converted to tons of $\mathrm{CO}_{2}$ equivalent by multiplying it by $44 / 12$, or 3.67 as indicated by (Pearson et al., 2007).

\section{Data Analysis}

After the data collection was completed, data analysis of various carbon pools measured in the forests were accomplished by organizing and recording on the excel data sheet. The data obtained from $\mathrm{DBH}$, diameter, height of each species, field weight $\left(\mathrm{W}_{\mathrm{w}}\right)$, fresh weight-(FW) and dry weight $\left(\mathrm{W}_{\text {dry }}\right)$ of $L H G$ and soil were organized by excel 2007 and analyzed using and MINITAB software version 16 . DBH data was arranged in classes $\leq 10,>10-20,>20$ $30,>30-40$ and $>40$ for applying appropriate model of biomass estimation equation. The relationship between each parameter was tested by descriptive statistics. Differences at the $95 \%(\alpha=0.05)$ confidence interval was used to see the significance differences.

\section{RESULTS}

The carbon stock value of the study site in different carbon pools showed different storage of Carbon. About $47 \%$ of the biomass was contained in above ground, while below ground biomass comprised $9.53 \%$ of the total biomass. It was found that about $42.7 \%$ of the biomass was contained in the soil. The carbon stock that was stored in the dead wood biomass was $0.128 \%$ and carbon in litter biomass was almost negligible amount (0.0033\%). The mean carbon density in all carbon pool of the study site was 568.314 ton/ha. The overall summary of mean biomass and carbon stock in all plots of the study site is shown in Tables 1 and 2.

Table 1: Summary of mean biomass and carbon stock of AGB, AGC, BGB, BGC, LB, LC, DWB DWC and SOC (ton/ha) of the study site.

\begin{tabular}{cccccccccc}
\hline Total No of plots & \multicolumn{10}{c}{ Different Carbon pools } \\
\hline \multirow{2}{*}{54} & AGB & BGB & LHGB & DWB & AGC & BGC & DWC & LHGC & SOC \\
\cline { 2 - 10 } & 994.16 & 198.84 & 0.69 & 2.66 & 270.89 & 54.18 & 0.725 & 0.019 & 242.5 \\
\hline
\end{tabular}

Table 2: Percentage biomass and carbon density in the different carbon pools

\begin{tabular}{cccccccccc}
\hline Total No of plots & \multicolumn{10}{c}{ Different Carbon pools } \\
\hline \multirow{3}{*}{54} & AGB & BGB & LHGB & DWB & AGC & BGC & DWC & LHGC & SOC \\
& $(\%)$ & $(\%)$ & $(\%)$ & $(\%)$ & $(\%)$ & $(\%)$ & $(\%)$ & $(\%)$ & $(\%)$ \\
\cline { 2 - 10 } & 79.778 & 19.944 & 0.058 & 0.22 & 47 & 9.3 & 0.128 & 0.0033 & 42.7
\end{tabular}

(AGB: Above ground biomass; AGC: Above ground carbon; BGB: Below ground biomass; BGC: Below ground carbon;

LB: Litter Biomass; LC: Litter carbon; DWB dead wood biomass, DWC: dead wood carbon and SOC: Soil organic carbon)

Factors affecting the Carbon Stocks of the Study Site

There are different factors that affect the storage of carbon in forests. Among the many factors, altitude, slope and aspect have a pronounced effect on carbon concentration. Each is discussed as follow.

\section{Carbon Stocks of Different Pools and Altitudinal Variation}

The presence of variation in altitudinal gradient affects the carbon stock of different pools in the forest. The lower parts of altitude is high in above ground carbon stocks while the upper and middle parts of altitude have low to moderate carbon stocks in above ground biomass (Table 3). However, 318.8174, 258.247 and 240.6356 ton/ha carbon stocks were recorded at the lower, middle and upper altitude respectively in above ground biomass. Similar trend was shown in below ground biomass in which $63.76,51.65$ and 51.64 ton/ha carbon stocks were recorded in the lower, middle and upper altitude respectively with highest value found at the lower part of 
Tibebu Yelemfrhat et al.,

altitudinal classes followed by the middle and upper parts. But this is not very much significance at $95 \%$ confidence interval $(F=0.618, P=0.543)$ in $A G C$ and $(F=0.618$, $P=0.543$ ) in BGC stocks. It is also the same in the case of litter carbon stock and SOC. With significance difference at $\alpha=0.059(F=0.991, P=0.378)$ in litter carbon stock and $(F=0.653, P=0.525)$ SOC stocks. The litter and SOC carbon stock were higher in the lower parts of altitude and
Sci. Technol. Arts Res. J., July-Sep 2014, 3(3): 29-36

low in the upper altitude. 243.943, 240.3293 and 240.1949 ton/ha stocks of carbon were recorded in the lower, middle and upper altitude respectively in the soil pool. In general, the lower part of the altitude contains more carbon stocks (243.943 ton/ha), followed by the middle (240.329 ton/ha) and the upper altitudinal gradient (240.194 ton/ha).

Table 3: Mean biomass and carbon stocks (t ha-1) in different carbon pools along altitudinal gradient

\begin{tabular}{ccccccccc}
\hline $\begin{array}{c}\text { Altitude } \\
\text { Class }\end{array}$ & $\begin{array}{c}\text { Altitude } \\
\text { range }(\mathbf{m})\end{array}$ & $\begin{array}{c}\text { No of } \\
\text { Plots }\end{array}$ & AGC & BGC & LC & DWC & SOC & $\begin{array}{c}\text { Total carbon } \\
\text { Stock ton/ha }\end{array}$ \\
\hline Lower & $2473-2542$ & 18 & 318.817 & 63.7635 & 0.896 & 0.021 & 243.943 & 627.014 \\
Middle & $2543-2614$ & 19 & 258.247 & 48.1271 & 0.255 & 0.017 & 240.329 & 550.730 \\
Upper & $2615-2900$ & 17 & 240.635 & 51.6494 & 0.459 & 0.016 & 240.195 & 542.582 \\
\hline
\end{tabular}

\section{Carbon Stocks of Different Pools and Slope Gradient}

The slope gradient was also a second factor which affects the carbon stocks of different pools in the studied forest (Table 4). Above ground biomass and below ground biomass and their consecutive carbon stocks were found to be low in hilly areas of the forest due to the fact that no more vegetations cover were found there. The carbon stock of the middle slope gradient was moderate in both above ground carbon and below ground carbon stocks and higher in the upper slope gradient in both pools. $316.172,260.355$ and 187.128 ton/ha carbon stocks were recorded at the lower, middle and upper slope gradient respectively in above ground carbon stocks. Similar trend was also shown in below ground biomass in which $63.234,52.071$ and 37.426 ton/ha carbon stocks were recorded in the lower, middle and higher slope classes respectively with highest value found at the lower of slope classes followed by the middle and upper slope classes.
But this was not statistically significance at $\alpha=0.05(F=$ $0.169, P=0.845)$ in above ground biomass and $(F=0.169$, $P=0.845$ ) in below ground biomass. At the same in the case of dead wood, litter carbon stock and SOC, there was no significance difference at $\alpha=0.05$. The litter carbon stock was higher in the lower slope classes and low in the higher slope classes with its value arranged $0.020,0.0171$ and 0.017 ton/ha in the lower, middle and higher slope gradient respectively. The carbon stock in the soil pool was higher in lower slope classes and lower in the upper slope classes with moderate carbon stocks in the middle slope classes. 246.417, 244.453 and 240.974 ton/ha stocks of carbon were recorded in the lower, middle and upper slope classes respectively in the soil pool. However, for dead wood carbon stock higher carbon stock in higher slope class (1.466 ton/ha) with lower in the lower slope class (0.290) and moderate stock in the middle slope class $(0.421$ ton/ha).

Table 4: Carbon stocks in different pools with respect to slope gradient

\begin{tabular}{ccccccccc}
\hline $\begin{array}{c}\text { Slope } \\
\text { Class }\end{array}$ & $\begin{array}{c}\text { Slope } \\
\text { Range (\%) }\end{array}$ & No of Plots & AGC & BGC & LC & DWC & SOC & $\begin{array}{c}\text { Total carbon } \\
\text { Stock ton/ha }\end{array}$ \\
\hline Lower & $>20$ & 22 & 187.128 & 37.426 & 0.017 & 1.466 & 240.974 & 487.396 \\
Middle & $>10-20$ & 23 & 260.355 & 52.071 & 0.017 & 0.421 & 244.453 & 557.005 \\
Upper & $0-10$ & 9 & 316.172 & 63.234 & 0.020 & 0.290 & 246.417 & 625.877 \\
\hline
\end{tabular}

\section{Carbon Stocks of Different Pools and Aspect}

Aspect was another parameter that affects the carbon stocks of different pools through which the direction of the plots were found to determine in which direction the highest and lowest carbon stocks is found in the study forest (Table 5). Based on the result that obtained, the mean AGC stock was lowest in South (257.37 ton/ha) and highest in North (296.98 ton/ha). Similar trend was observed for carbon stocks in below ground carbon pool with the highest value 59.39 ton/ha in north $(\mathrm{N})$ direction and lower in south direction (51.4738 ton/ha). On the other hand, the highest carbon stocks in litter biomass was recorded in the $\mathrm{N}(0.0213 \mathrm{ton} / \mathrm{ha})$ and the minimum carbon stock was recorded in East (E) (0.0147 ton/ha aspect. For dead wood carbon minimum value was in West (W) (1.2381ton/ha) and maximum value in South(S) aspect. The carbon stocks in soil was also recorded the minimum value in south (S) (227.0692ton/ha) and the highest or maximum value west (W) (263.33 ton/ha) in aspect. In all carbon pools there was a no significance difference in carbon stocks of the forest at 95\% confidence interval $(\alpha=0.05)$ except in dead wood carbon (Table 6) which had significant value $(F=2.295, P=$ 0.043).

Table 5: Mean carbon stocks (ton/ ha) different pools in different aspect

\begin{tabular}{cccccccc}
\hline Aspect & $\begin{array}{c}\text { No of } \\
\text { plots }\end{array}$ & $\begin{array}{c}\text { ABGC } \\
\text { (ton/ha) }\end{array}$ & $\begin{array}{c}\text { BGC } \\
\text { (ton/ha) }\end{array}$ & $\begin{array}{c}\text { DWC } \\
\text { (ton/ha) }\end{array}$ & $\begin{array}{c}\text { LC } \\
\text { (ton/ha) }\end{array}$ & $\begin{array}{c}\text { SOC } \\
\text { (ton/ha) }\end{array}$ & $\begin{array}{c}\text { Total carbon } \\
\text { Stock ton/ha }\end{array}$ \\
\hline E & 13 & 278.591 & 55.718 & 0.259 & 0.015 & 249.442 & 584.025 \\
N & 11 & 296.983 & 59.397 & 0.305 & 0.021 & 230.495 & 587.202 \\
S & 18 & 257.369 & 51.474 & 0.497 & 0.021 & 227.069 & 536.431 \\
W & 12 & 258.913 & 51.783 & 1.238 & 0.016 & 263.326 & 575.277 \\
\hline
\end{tabular}


Table 6: One-way ANOVA results of the three factors indicated above were shown below to show a significance difference in the carbon stocks values of different pools

\begin{tabular}{cccc}
\hline $\begin{array}{c}\text { Environmental } \\
\text { factors }\end{array}$ & $\begin{array}{c}\text { Carbon } \\
\text { pools }\end{array}$ & F-value & P-value \\
\hline & AGC & 0.618 & 0.543 \\
Altitude & BGC & 0.618 & 0.543 \\
& DWC & 3.339 & $\mathbf{0 . 0 4 3}$ \\
& LC & 0.991 & 0.378 \\
& SOC & 0.653 & 0.525 \\
\hline Slope & AGC & 0.169 & 0.845 \\
& BGC & 0.169 & 0.845 \\
& DWC & 1.107 & 0.338 \\
& LHGC & 0.54 & 0.586 \\
Aspect & SOC & 0.077 & 0.926 \\
\hline & AGC & 0.512 & 0.821 \\
& BGC & 0.512 & 0.821 \\
& DWC & 2.295 & $\mathbf{0 . 0 4 3}$ \\
& LC & 0.422 & 0.884 \\
& SOC & 1.86 & 0.099 \\
\hline Bold values are significant at $\alpha=0.05(95 \%)$
\end{tabular}

\section{DISCUSSION}

\section{Storage of Biomass in Different Pools}

The maximum above ground biomass per plot was 1795.64 ton/ha and the minimum was 162.10 ton/ha. The average biomass stock recorded in above ground biomass was 576.36 ton/ha. The results are more or less similar to the previous researches of above ground biomass of afromontane forest which were 403 ton/ ha, $754.5 \mathrm{ton} / \mathrm{ha}$, and $567.2 \mathrm{ton} / \mathrm{ha}$ as indicated by (Getachew Tesfaye, 2007). The average above ground biomass observed from these three location was 574.89 ton/ha. The global above ground biomass in tropical dry and wet forests ranged between 30-275 ton/ha and 2131173 ton/ha respectively as indicated by Murphy and Lugo (1986), which is lower than the above ground biomass of Tara Gedam forest (Table 7).
In this study, the differences in biomass and carbon accumulation among plots could be largely due to differences in the growth rates of plants as indicated by (Redondo, 2007). Litter constitutes an important flux of soil organic Carbon. The forest litter consisted of a relatively high number of trees, although the density varies among samples and species; in densely populated trees few litters were found due to the closeness of plants each other makes their litter not fall down (Demel Teketay, 1996). The Carbon stocks in the litter of the study forest ranged from 2.6-3.8 ton/ha which were comparable to those reported for tropical seasonal rainforests (1.4 ton/ha) carbon and tropical secondary forest at the Makiling Forest Reserve in the Philippines (1.9 ton/ha) Lasco et al. (2004). On the other hand, the litter carbon varies on other tropical forests (2.6-3.8 ton/ha) as reported by Brown and Lugo (1989). The relatively low quantities of Carbon stored in litter carbon stock in the studied forest may be due to the high decomposition rate as reported in a 10-year study by Tang et al. (2010) and Seasonal Wild fire distraction in some part of the forest and caring number of cattle during the winter that affect the litter carbon stock directly in the area.

The average values of soil organic carbon in the study area was 242.507 ton/ha, which was similar to the Carbon density estimates of Afromontane Rain Forests of the Eastern Arc Mountains which were found to be between 252 and 581 ton/ha as indicated by (Munishi (2001); Munishi and Shear (2004). The distribution of Carbon stocks in each sample plot of the study forest is known to vary due to the presence of different tree species, soil nutrient availability, climate, and topography and disturbance regime (Houghton, 2005). This indicates that, the higher soil organic carbon in the soil could sequester more $\mathrm{CO}_{2}$. The bulk density of the soil in this study was found to be $0.78 \mathrm{~g} / \mathrm{cm}^{3}$ minimum value and 0.999 $\mathrm{g} / \mathrm{cm}^{3}$ maximum value with an average value of 0.93 $\mathrm{g} / \mathrm{cm}^{3}$. The presence of low bulk density in the soil indicates that the soil has high potentials to accumulate large amount of organic matter in it (Brady, 1974).

Table 7: Comparison of carbon stock (ton/ ha) of the present result with other studies (AGC- Above ground carbon; BGC- Below ground carbon; DWC-Dead wood carbon: LC- Litter carbon; SOC- Soil organic carbon).

\begin{tabular}{lccccc}
\hline \multicolumn{1}{c}{ Study places } & AGC & BGC & DWC & LC & SOC \\
\hline Menagasha Sub a State Forest (Mesfin Sahile, 2011) & 133 & 26.6 & - & 5.26 & 121.28 \\
Selected Church Forest (Tulu Tola, 2011) & 122.85 & 24.57 & - & 4.95 & 135.94 \\
Tara Gedam Forest (Mohammed Gedefaw,2013) & 306.36 & 61.272 & - & 0.9 & 274.32 \\
SMNP lowland forest (Tibebu Yelemfrhat, 2014) & 270.89 & 54.178 & 0.726 & 0.017 & 242.51 \\
\hline
\end{tabular}

\section{Environmental Factors Affecting the Carbon Stocks of Different Pools}

Most of the time altitudinal gradient slope and aspects were the factors that affect the storages of carbon in different pools. As observed, Powers and Schlesinger (2002) a strong effect of slope and aspect on the SOC stock of a subalpine forest in the Olympic Mountains of Washington state. The carbon stock of the study forest was highest at the lower altitudinal range followed by the medium and lowest at higher altitude of the mountain. This is due to the decreasing of layer of large DBH trees at higher altitudinal range of the forest site and the layer of large DBH trees increases towards the lower altitudinal ranges naturally and trees and shrub deforestation was also higher in upper altitude. Especially, altitudinal variation has an impact on AGC, BGC and SOC stock because of its influence on soil water regime Richards (1996). Similarly the carbon stock of the study forest was increased as the degree of slope gradient decreased. This is due to the inclined arrangement of the study forest that affects both forest biomass and soil nature of the area. Most steep areas were covered by lower plants (grasses, herbs and bushes) which have lower biomass and carbon relatively. In addition, the highest carbon stock was found in the North and Eastern aspect and the least in the south part of the forest due to the availability of moisture (large rivers), soil fertility and better solar radiation in the Eastern aspect. 


\section{CONCLUSIONS}

The study conducted in low land forest of Simien Mountain National Park showed that the forest contains moderately diversified plant species. A total of twenty different species of plants were collected, of which Erica arborea was the dominant in density and Buddeleia polystachya was the least dominant in the study site. Based on $\mathrm{DBH}$ and height class distribution the forest has a bit different trends observed in both classes. The densities of tree species decreases as the height class increases but For $\mathrm{DBH}$, it has an irregular pattern. This implies that, the predominance of small sized tree and shrub species in the lower classes than in the upper classes. The analysis of these two parameters in the study forest indicated that higher percentage of number of tree species in the lower than in the higher height frequency classes. The carbon stocks of the study site shows a variation among the plots due to the presence of higher biomass in some plots and small biomass in other plots. The average carbon stock of the different carbon pools of this study was almost similar with most researches done in tropics and Ethiopia. The ANOVA result showed that at $95 \%$ confidence interval, the carbon stocks in the different carbon pools (AGC, BGC, DWC, LHGC and SOC) were different due to environmental factors (altitude, slope and aspect). The lower parts of altitude class carbon stock potential were higher in all pools (except for the DWC pool which is significant for most carbon pools) while the upper and medium parts of altitude had low to moderate carbon stock. This is due to the fact that there were dense vegetation cover in the lower altitudinal range and the presence of favorable conditions in this part. DWC was higher in higher altitude and low to moderate in medium and lower altitude. This is because the higher altitude part of the forest was under less nutrient and different environmental factors like landslide and erosions that facilitate dead wood accumulation. At same time the litter and soil carbon stocks were higher in the lower parts of altitude and slope with lower in the higher altitude due to the presence of large decides forest and by the nature of the lower part to receive the medium and higher feeds to down. The carbon stock of the higher slope gradient was lower in all four pools (AGC, BGC, LHGC, and SOC) and higher to moderate stock in lower and medium slope gradients. This is because the better density of the study forest was found in lower and medium slope area due to the presence of stable environmental conditions better relative disturbance. But DWC was higher in higher slope because environmental pressure is high in this range which affects plant life span. The mean AGC and BGC stocks were lowest in Southern part of the forest and highest in Northern parts. On the other hand, the highest carbon stocks in litter biomass were recorded in the Northern part and the minimum carbon stock was recorded in eastern aspect. The carbon stocks in soil were also recorded the minimum value in southern part and the peak value in the western part of the forest. In general, the carbon stocks in the different pools were arranged in this order $\mathrm{N}>\mathrm{E}>\mathrm{W}>\mathrm{S}$.

\section{REFERENCES}

Abel Grima, Teshome Soromessa and Tesfaye Bekele (2014). Forest Carbon Stocks in Woody Plants of Mount Zequalla Monastery and It's Variation along Altitudinal Gradient: Implication of Managing Forests for Climate Change Mitigation. Science Technology and Art Research Journal 3(2): 133-141.
Adugna Feyissa, Teshome Soromessa and Mekuria Argaw (2013). Forest Carbon Stocks and Variations along Altitudinal Gradients in Egdu Forest: Implications of Managing Forests for Climate Change Mitigation. Science Technology and Art Research Journal 2(4): 40-46.

Birhanu Kebede, Teshome Soromessa and Ensermu Kelbessa (2014). Endemic plant species composition and their status in Gedo dry evergreen montane forest, West Shewa Zone of Oromia national regional state, Central Ethiopia. Science Technology and Art Research Journal 3(2): 121-133.

Batjes, N.H. and Sombroek, W.G. (1997). Possibilities for carbon sequestration in tropical and subtropical soils. Global Change Biology 3: 161-173.

Belay Melese Wolde, Ensermu Kelbessa and Teshome Soromessa (2014). Forest Carbon Stocks along with Environmental Gradients in Woody Plants of Arba Minch Ground Water Forest, Southern Ethiopia. Science Technology and Art Research Journal 3(2): 142-148.

Bhishma, P.S., Shiva, S.P., Ajay, P., Eak, B.R., Sanjeeb, B., Tibendra, R.B., Shambhu, C., and Rijan, T. (2010). Forest Carbon Stock Measurement: Guidelines for measuring carbon stocks in community-managed forests. Funded by Norwegian Agency for Development Cooperation (NORAD). Asia Network for Sustainable Agriculture and Bioresources (ANSAB) publishing, Kathmandu, Nepal, pp.17-43.

Brady, N. C. (1974). The Nature and Properties of Soils, $8^{\text {th }}$ ed., Macmillan, New York.

Brown, S.A.J., Gillespie, J.R. and Lugo, A.E.(1989). Biomass estimation methods for tropical forests with application to forest inventory data. Forest Science 35(4): 881-902.

Brown, S. (1997). Estimating biomass and biomass change of tropical forests: a Primer. FAO Forestry Paper 134: 120-130.

Cairns, M.A., Brown, S., Helmer, E.H., Baumgardner, G.A. (2003). Root biomass allocation in the world's upland forests. Oecologia 111: 1-11.

Demel Teketay (1996). Germination ecology of 12 indigenous and 8 exotic multipurpose leguminous species from Ethiopia. Forest Ecology and Management 80: 209-223.

Ensermu Kelbessa and Teshome Soromessa. (2008). Interfaces of Regeneration, Structure, Diversity and Uses of Some woody Species in Bonga Forest, a Unique Gene Reserve for Wild Coffee. SINET: Ethiopian Journal of Sciences 31(2): 121-134.

Fekadu Gurmessa, Teshome Soromessa and Ensermu Kelbessa (2011). Florisitc Composition and Community analysis of Komto Afromontane Moist Forest of East Wellega, West Ethiopia. Science Technology and Art Research Journal 2(2): 58-69.

Fekadu Gurmessa, Teshome Soromessa and Ensermu Kelbessa (2012). Structure and Regeneration status of Komto Afromontane Moist forest, East Wellega Zone, West Ethiopia. Journal of Forestry Research 23(2): 205216.

Geider, J.R., Delucia, H.E., Falkowsk, G.P., Finzi, C.A., Grime, P.J., Grace, J., Kana, M.T., Roche, J. (2001). Primary productivity of planet earth: biological determinants and physical constraints in terrestrial and aquatic habitats. Global Change Biology 7 : 849-882.

Getachew Tesfaye. (2007). Structure, biomass and net primary production in a dry tropical afromontane forest in Ethiopia.Addis Ababa University, Ethiopia; Institute of biodiversity Conservation, Ethiopia; and Ethiopian Tree Fund Foundation, Ethiopia. 
Tibebu Yelemfrhat et al.,

Hairiah, K., Sitompul, S.M. van Noordwijk M. and Palm C. (2001). Methods for sampling carbon stocks above and below ground. International Centre for Research in Agroforestry; Bogor, Indonesia.

Houghton, R.A. (2005). Aboveground forest biomass and the global carbon balance. Global Change Biology 11: 945958.

Inter-governmental Panel on Climate Change (2006). IPCC Guidelines for National Greenhouse Gas Inventories. National Greenhouse Gas Inventories Program, IGES, Japan.

Kirschbaum, M.U.F. (1996). The carbon sequestration potential of tree plantations in Australia. In: (eds.), Environmental Management: The Role of Eucalypts and Other Fast Growing Species, Eldridge, K.G., Crowe, M.P. Old, K.M. Forestry and Forest Products, 20:77-89.

Lasco, R.D., Guillermo, I.Q., Cruz, R.V.O., Bantayan, N.C. and Pulhin, F.B. (2004). Carbon stocks assessment of a secondary forest in Mount Makiling Forest Reserve, Philippines. Journal of Tropical Forest Science16: 35-45.

Lüe, T., Yin, J.X., Jepsen, M.R. and Tang, J.W. (2010). Ecosystem carbon storage and partitioning in a tropical seasonal forest in Southwestern China. Forest Ecology and Management 260: 1798-1803.

MacDicken, K.G. (1997). A Guide to Monitoring Carbon Storage in Forestry and Agro- forestry Projects. In: Forest Carbon Monitoring Program. Winrock International Institute for Agricultural Development, Arlington, Virginia.

McDowell, N. (2002). Developing countries to gain from carbon trading fund. Metz, B., O.Davidson, R. Swart, and J. Pan. (2001). Climate Change Mitigation: Cam bridge, U.K.: Cambridge University Press.

Mesfin Sahile (2011). Estimating and Mapping of Carbon Stocks based on Remote Sensing, GIS and Ground Survey in the Menagesha Suba State Forest. M.Sc. Thesis, Addis Ababa University, Addis Ababa.

Mohammed Gedefaw (2013). Forest carbon stocks in woody plants of Tara Gedam forest and its variations along environmental factors: Implication for climate change mitigation, in South Gondar, Ethiopia.

Mohammed Gedefaw, Teshome Soromessa and Satishkumar Belliethathan (2014). Forest Carbon Stocks in Woody Plants of Tara Gedam Forest: Implication for Climate Change Mitigation. Science Technology and Art Research Journal 3(1): 101-107.

Mohammed Gedefaw and Teshome Soromessa (2014). Status and Plant Species Diversity in Tara Gedam Forest, Ethiopia. Science Technology and Art Research Journal 3(2): 114-120.

Munishi, P.K.T. and Shear, T.H. (2004). Carbon storage in afromontane rain forests of the Eastern Arc Mountains of Tanzania: their net contribution to atmospheric carbon. Journal of Tropical Forest Science 16: 78-93.

Munishi, P.K.T. (2001). The Eastern Arc Mountains Forests of Tanzania: Their Role in Biodiversity and Water Resources Conservation and Net Contribution to Atmospheric Carbon. PhD Thesis, North Carolina State University, Raleigh, NC USA. pp.128.

Murphy, P. G. and Lugo, A. E. (1986). Ecology of tropical dry forest. Annual Review of Ecological System17: 67-88.

Pearson, T.R., Brown, S.L. and Birdsey, R.A. (2007). Measurement guidelines for the sequestration of forest carbon: Northern research Station, Department of Agriculture, Washington, D.C, pp. 6-15.

Pearson, T., Walker, S. and Brown, S. (2005). Sourcebook for land-use, land-use change and forestry projects: Win
Sci. Technol. Arts Res. J., July-Sep 2014, 3(3): 29-36

rock International and the Bio-carbon fund of the World Bank. Arlington, USA, pp. 19-35.

Powers, J.S., Schlesinger, W.H. (2002). Relationships among soil carbon distributions and bio physical factors at nested spatial scales in rainforests of northeastern Costa Rica. Geoderma 109:165-190.

Richards, P.W. (1996). The tropical rain forest, 2nd edn. Cambridge, CUP. Russell, A.E., Raich, J.W., Valverde, O.J., Fisher, R.F. (2007). Tree species effects on soil properties in experimental plantations in tropical moist forest. Soil Science Society American Journal 71: 13891397.

Schlesinger, W.H. (1991). Biogeochemistry, an Analysis of Global Change. New York, USA, Academic Press.

Siry, J., Bettinger, P., Borders, B., Cieszewski, C., Clutter, M., Izlar, B., Markewitz, D., Teskey, R. (2006). Forest Carbon Estimation Protocol for the State of Georgia, USA

Sombroek, W.G., Nachtergaele, F.O. and Hebel, A. (1993). Amounts, dynamics and sequestering of carbon in tropical and subtropical soils. Ambio 22: 417-426.

Tang, J.W., Cao, M., Zhang, J.H., Li, M.H. (2010). Litterfall production, decomposition and nutrient use efficiency varies with tropical forest types in Xishuan gbanna, SW China: a 10-year study. Plant and Soil 335: 271-288.

Teshome Soromessa., Demel Teketay and Sebsebe Demissew. (2004). Ecological study of the vegetation in Gamo Gofa zone, Southern Ethiopia. Tropical Ecology 45(2): 209-221.

Teshome Soromessa, Ensermu Kelbessa, Afework Bekele, Getinet Masresha, Desalegn Ejigu, Melese Yihuneand Fissehaltanna (2011). Current Status and Significance of Faunal and Floral Diversity of the Simien Mountains, Northern Ethiopia. Poster presented on December 30-31, 2011 during the conference organized by Addis Ababa University, Addis Ababa, Ethiopia.

Teshome Soromessa (2013). Ecological Phytogeography: A Case Study of Commiphora Species. Science Technology and Art Research Journal 2(3): 93-104.

Teshome Soromessa and Ensermu Kelbessa (2013a). Diversity, Ecology and Regeneration Studies of Bonga, Borana and Chilimo Forests of Ethiopia. Lambert Academic Publishing, Saarbrücken, Germany, Pp 140, ISBN 978-3-659-41509-8.

Teshome Soromessa and Ensermu Kelbessa (2013b). Diversity and Endemicity of Chilimo Forest, Central Ethiopia. Bioscience Discovery 4(1): 1-4.

Teshome Soromessa., Ensermu Kelbessa (2014). Interplay of regeneration, structure and uses of some woody species in Chilimo Forest, Central Ethiopia. Science Technology and Art Research Journal 3(1): 90-100.

Tulu Tola. (2011). Estimation of carbon stock in church forests: implications for managing Church forest for carbon emission reduction.

UNFCCC (1997). Kyoto Protocol to the United Nation Framework Convention on Climate Change. Retrieved 18/09/2010, from http://unfccc.int. University Press, Cambridge, UK.

Wulder, M.A., White, J.C., Fournier, R.A., Luther, J.E., and Magnussen, S. (2008). Spatially Explicit Large Area Biomass Estimation: Three Approaches Using Forest Inventory and Remotely Sensed Imagery in a GIS. Sensors 8: 529-560.

Yitebitu Moges, Zewdu Eshetu and Sisay Nune (2010). Manual for assessment and monitoring of carbon in forest and other land uses in Ethiopia (Draft), Ethiopian Forest Research Center, Addis Ababa, Ethiopia. 